\title{
Youth Perspectives from Rapidly Changing Landscapes: Lessons from Peru
}

Julia Quaedvlieg*, Carla Merediz, Mishari Garcia Roca, Katya Mallea Diaz, Eber Cabanillas Suarez, and Miguel Zamaolla Condori.

\section{Summary}

In Peru, migration into, within, and out of Amazonia has long existed, although drivers of mobility vary and remain subject to changes in socio-cultural and political processes. Indigenous and non-indigenous people in the region have moved in search of food, land, other sources of livelihood, while some groups have been forced to leave their territories (Garcia \& Surrallés 2009; Hecht et al. 2015). Improved infrastructure and an increased demand for natural resources in recent years have led to an increase in migration rates to the region (Dourojeanni et al. 2008).

In the Peruvian Amazonian region of Madre de Dios, most inhabitants are first- or second-generation immigrants mainly from Peru's Andean regions. Even the majority of Indigenous peoples in the region originate from other areas. Although it is among the most isolated parts of the country $-141,000$ inhabitants spread out across 85 million hectares - Madre de Dios has among Peru's highest immigration rates. The population grew by almost 30\% during the period 2007-2017 (INEI 2018), with the lure of gold mining a huge draw to workers from the impoverished highlands.

The influx of migrants, as well the growth in extractive industries, have had a significant impact. Forest landscapes and forest communities are changing rapidly, both due to newly created opportunities and threats posed to the environment and human health. It is within this context that young people living in Madre de Dios are choosing to remain in or leave their forest homes as they aspire to better paid work and improved living conditions.

Drawing on insights from a three-day workshop held with local youth, as well as our extensive lived and professional experiences, we describe patterns of youth migration in Madre de Dios, the motivations for youth to migrate or to stay in their communities, and the implications for rural areas. A lack of access to further education and limited income opportunities encourage youth to leave for urban centres. Although most youngsters talk about returning to live in their home communities, we argue that emergent rural-urban linkages may consolidate migrant-village ties but make it unlikely that such youth will make the forest their principal home over the long-term.

\section{$\underline{\text { References }}$}

Dourojeanni, M., Alberto B., and D. Dourojeanni. 2008. Amazonía peruana en 2021. Explotación de recursos naturales e infraestructuras: ¿Qué está pasando? ¿Qué es lo que significan para el futuro? ProNaturaleza, Lima.

García Hierro, P., and A. Surrallés. 2009. Antropología de un derecho. Libre determinación territorial de los pueblos indígenas como derecho humano. IWGIA, Lima.

Hecht, S., Yang, A.L., Basnett, B.S., Padoch, C. and Peluso, N.L., 2015. People in motion, forests in transition: trends in migration, urbanization, and remittances and their effects on tropical forests (Vol. 142). CIFOR. 
INEI, 2018. Censos Nacionales 2017: XII de Población y VII de Vivienda. Perú: Crecimiento y distribución de la población. Lima. 